Komunitas 3 (1) (2011):40-50
Jttp://journal.unnes.ac.id/nju/index.php/komunitas

\title{
SISTEM BUDAYA BAHARI KOMUNITAS NELAYAN LUNGKAK DESA TANJUNG LUAR, LOMBOK TIMUR, NUSA TENGGARA BARAT
}

\section{Fadly Husain $\bowtie$}

Jurusan Sosiologi dan Antropologi, Fakultas Ilmu Sosial, Universitas Negeri Semarang, Indonesia

\section{Info Artikel}

\section{Sejarah Artikel:}

Diterima Desember 2010

Disetujui Januari 2011

Dipublikasikan Maret 2011

\section{Keywords:}

maritime culture;

lombok island;

knowledge system.

\begin{abstract}
Abstrak
Tujuan penelitian ini adalah mengetahui bagaimana sistem pengetahuan komunitas nelayan Lungkak sebagai salah satu kearifan lokal dan modal sosial dalam mengelola dan memanfaatkan sumberdaya laut. Penelitian dilakukan dengan metode kualitatif dengan tipe penelitian deskriptif. Lokasi penelitian tersebut ditentukan secara purposive menurut pokok permasalahan penelitian yang dirumuskan. Data kualitatif akan dikumpulkan melalui wawancara mendalam (In-depth Interview) dan pengamatan terlibat (observation participation). Dalam penelitian ini pengolahan dan analisis data dilakukan secara bersamaan dalam sebuah proses yang dilakukan secara terus menerus sejak pengumpulan data dilakukan khususnya dalam proses pengorganisasian, pemilihan, dan kategorisasi antar data dalam bentuk uraian naratif atau thick description. Komunitas nelayan Lungkak mempunyai kearifan lokal berupa sistem pengetahuan tentang pengelolaan dan pemanfaatan sumberdaya laut. Sistem pengetahuan ini berupa pengetahuan tentang biota laut bernilai ekonomi, pengetahuan tentang tempat penangkapan dan posisi rumah ikan, pengetahuan tentang musim (Pola musim dan waktu-waktu munculnya ikan), pengetahuan tanda-tanda di laut dan di angkasa, pengetahuan tentang lingkungan sosial budaya, sistem keyakinan/ kepercayaan (upacara/ritual dan pantangan-pantangan).
\end{abstract}

\begin{abstract}
The purpose of this study was to determine how knowledge system of fishing community of Lungkak as one of the local knowledge and social capital in managing and utilizing their natural resources. The study was conducted with qualitative methods with the type of descriptive research. The study site is purposively determined according to basic research problems formulation. Qualitative data will be collected through in-depth interview and participation observation. In this study the processing and data analysis carried out simultaneously in a process that is conducted continuously since data collection is done especially in the organizing process, selection, and categorization between data in the form of thick description or narrative description. Fishing community of Lungkak has a system of local knowledge in management and utilization of marine resources. Knowledge system is a knowledge of the economic value of marine life, the knowledge of the location and the location of the house catching fish, the knowledge of the seasons (winter pattern and emergence times of fish), the knowledge of the signs at sea and in space, the knowledge of the socio-cultural environment, system of beliefs (rituals and taboos).
\end{abstract}

(C) 2011 Universitas Negeri Semarang 


\section{PENDAHULUAN}

Indonesia merupakan negara maritim terbesar di dunia. Menurut Badan Koordinasi Survey dan Pemetaan Nasional tahun 2006, Indonesia memiliki luas laut sekitar 3.3 juta $\mathrm{km}^{2}$ (Badan Pusat Statistik : 2010). Dengan luas laut yang begitu besar, Indonesia menyimpan potensi sumberdaya kelautan dan perikanan yang sangat penting bagi masyarakatnya. Meskipun demikian diperlukan pengkajian dari berbagai disiplin ilmu agar proses pengelolaannya berjalan efektif. Naping (2003) menjelaskan bahwa laut Indonesia merupakan wilayah yang penuh daya tarik dan menantang dari sudut pengkajian berbagai ilmu pengetahuan. Hal ini memerlukan kajian multidimensi dan dari berbagai perspektif baik itu ekologis maupun sosial budaya karena ekosistem laut Indonesia terdapat banyak fenomena yang sangat menarik (Naping : 2003)

Pada sudut pandang sosiobudaya banyak hal yang menarik untuk dikaji temasuk diantaranya adalah sistem budaya kebaharian. Komunitas nelayan mempunyai sistem budaya yang unik dan berbeda dengan komunitas masyarakat agraris. Sistem pengetahuan yang dimiliki merupakan adaptasi dari lingkungan mereka yang berada pada wilayah pesisir dan laut. Wilayah pesisir tempat mereka hidup dan laut sebagai tempat menggantungkan hidupnya diperlukan sistem budaya yang mumpuni yang tercermin di dalam sistem pengetahuan nelayan baik dalam kehidupannya sehari-hari maupun pada saat menangkap ikan. Pengetahuan-pengetahuan ini muncul akibat dari gagasan bahwa kondisi laut yang berbahaya dan kondisi sumber daya laut yang tidak mudah dikelola menyebabkan pekerjaan menangkap ikan di laut penuh resiko bahaya mengenai keselamatan jiwa manusia, dan ketidakmenentuan dalam pendapatan nelayan (Acheson 1981). Faktor resiko yang dihadapi oleh nelayan ini juga akan berbeda pada masyarakat tradisional dan masyarakat modern diantaranya resiko sosial dan resiko teritorial (Smith : 1988).

Sebuah asumsi bahwa terdapat hubungan antara manusia dan lingkungannya dengan menggunakan sistem pengetahuannya atau kearifan lokalnya (Folke : 2004). Seperti halnya pada masyarakat nelayan yang berasumsi bahwa interaksi manusia dengan lingkungan lautnya berdasarkan atas pengetahuan dan konsep yang dimiliki mengenai arti baik itu konsumtif maupun non-konsumtif dari sumberdaya dan lingkungan dan fungsi serta manfaatnya bagi kehidupannya (Lampe : 2003). Selanjutnya menurut Lampe (2003) sebuah konsep baru muncul yaitu pentingnya kerjasama dan kelembagaan sebagai usaha untuk mendapatkan keperluan yang wajib ada dalam proses ekspoitasi seperti kapal, perahu dan peralatan lainnya serta modal. Hal tersebut sesuai dengan pendapat McCay (1988) yang menjelaskan perlunya kerjasama nelayan dalam mengatur sumberdaya alam lokal maupun secara komunitas. Dalam proses eksploitasi sumberdaya serta aktivitas laut lainnya nelayan memanfaatkan sistem pengetahuannya, kelembagaan (organisasi sosial, institusi), dan teknologi (peralatan, perlengkapan baik tradisional dan modern).

Khususnya sarana dan prasarana teknologi eksploitasi sumberdaya (fisik/material) meskipun masih menggunakan teknologi sesuai dengan pengetahuan lokalnya namun tidak menutup penggunaan teknologi modern. Teknologi modern memberi dampak yang sangat positif dalam pengelolaan sumber daya laut. Mulai dengan motorisasi pada tahun tahun 1970-an di Indonesia sampai pada penggunaan Information and Communication Technology (ICT) seperti Global Positioning System (GPS) yang digunakan oleh nelayan Venezuaela, Suriname dan Mexico (Kalman dan Correa : 2009).

Selain gagasan di atas yang perlu juga diketahui dalam rangka sistem budaya kebaharian yang mencakup sistem-sistem pengetahuan, kepercayaan, nilai dan norma dalam rangka pemanfaatan sumber daya laut. Hal ini dapat dilihat pada masyarakat nelayan Sri Lanka bahwa kesuksesan yang didapatkan adalah lebih kepada kekuatan supernatural (Pallson : 1988). Sistem pengetahuan berupa pengetahuan tentang biota laut yang benilai ekonomi, lokasi penangkapan, pola musim, tanda-tanda di laut dan angkasa, lingkungan sosialnya dan gagasan-gagasan tentang laut, serta taktik-taktik menangkap ikan seperti yang dilakukan oleh masyarakat nelayan Is- 
landia (Derrenberger \& Palsson : 1986), serta sistem keyakinan atau kepercayaan dan halhal yang dianggap tabu (lihat Poggie : 1980, Poggie, Pollnac dan Gersuny : 1976 dan Palmer : 1989).

Dari gagasan-gagasan inilah dapat diungkapkan bagaimana pengetahuan komunitas nelayan dalam rangka kehidupan kebaharian. Ini penting karena dari sinilah akan diidentifikasi keinginan-keinginan dan harapan komunitas nelayan maupun berbagai permasalahan yang dihadapi oleh sebagaian besar komunitas-komunitas yang mendiami seluruh wilayah pesisir Indonesia yang besar ini.

Pengetahuan-pengetahuan lokal atau kearifan lokal masyarakat sudah bayak dikaji khususnya bagi komunitas nelayan namun dengan luasnya wilayah pesisir dan Laut Indonesia, keberagaman budaya masyarakat serta subetnik yang hidup dalam suatu kebudayaan yang sama sekalipun, maka dari perspektif di atas dipandang perlu untuk melakukan suatu penelitian yang berfokus pada system pengetahuan kebaharian komunitas nelayan untuk identifikasi sistem budaya sebagai kearifan lokal.

\section{METODE PENELITIAN}

Penelitian tentang Sistem Pengetahuan Kebaharian Komunitas Nelayan dilaksanakan di Gili Beleq Desa Pemongkong Kecamatan Jerowaru Lombok Timur dengan metode deskriptif kualitatif. Data kualitatif diperoleh melalui wawancara mendalam (Indepth interview) dan pengamatan terlibat (observation participation). Data yang diperoleh dianalisa secara bersamaan dalam sebuah proses yang dilakukan secara terus menerus sejak pengumpulan data dilakukan, khususnya dalam proses pengorganisasi, pemilihan, dan kategorisasi antara data dalam bentuk uraian naratif atau thick description (Geertz, 1992). Deskripsi narasi tersebut merefleksikan berbagai hubungan-hubungan variabel sosial (domain) yang lahir dari proses interpretatif dan refleksif, sehingga hasil penelitian akan lebih obyektif dan kredibel (Spradley, 1997).

Fokus penelitian ini adalah pengeta- huan nelayan tentang biota laut bernilai tinggi, lokasi peangkapan ikan, tanda-tanda di laut dan angkasa, pengetahuan tentang lingkungan sosial budaya serta gagasan-gagasan tentang laut, serta sistem keyakinan atau kepercayaan yang mereka anut.

\section{HASIL DAN PEMBAHASAN}

Dusun Lungkak secara administratif masuk dalam wilayah pemerintantahan Desa Tanjung Luar Kecamatan Keruak Kabupaten Lombok Timur. Dusun ini adalah salah satu dusun dari sepuluh dusun yang ada di Desa Tanjung Luar. Adapun jumlah penduduknya sebanyak 1.674 jiwa (laki-laki 798 jiwa dan perempuan 876 jiwa) sedangkan jumlah rumah tangga sebanyak $484 \mathrm{KK}$. Mayoritas penduduknya menganut agama Islam.

Dusun Lungkak termasuk dalam kawasan wilayah pesisir kawasan Teluk Jukung. Kawasan ini merupakan kesatuan wilayah bersama Desa Tanjung, Desa Pijot, Pemongkong dan Desa Jerowaru Lombok Timur. Desa-desa tersebut memiliki kesamaan kepentingan dalam pemanfaatan dan pengelolaan sumberdaya perikanan laut dengan mayoritas penduduknya bermata pencaharian sebagai nelayan.

Komunitas Lungkak menurut cerita dari beberapa informan berasal dari keturunan etnis Bajo yang memang banyak mendiami wilayah Provinsi Nusa Tenggara Barat. Orang-orang Lungkak meyakini bahwa keturunan mereka berasal dari Sulawesi Selatan tempat etnis Bajo yang besar berasal. Walaupun di Sulawesi Selatan etnis Bajo merupakan sub etnis dari etnis Bugis dan Makassar disamping empat lainnya yaitu Mandar dan Toraja. Adanya hubungan etnik tersebut dapat dikenali dari informasi beberapa tokoh masyarakat bahwa Desa Tanjung Luar dan Lungkak bahwa yang pertama mengadakan upacara-uparara yang berhubungan dengan laut adalah keturunan raja Goa yang berasal dari Sulawesi-Selatan yang bernama Punggawa Rattung.

Pola pemukiman komunitas Lungkak adalah berbentuk kampung atau gubug yang saling berdekatan dan padat dengan jalan- 
jalan kecil. Meskipun agak jauh dari pusat desa Tanjung Luar akan tetapi tetap ramai pada saat-saat tertentu seperti pagi dan sore hari. Pada saat malam hari biasanya sangat sepi karena sebagian dari warganya turun ke laut mencari ikan khususnya yang laki-laki. Pada saat malam hari para perempuan tidak tampak keluar rumah karena ada keyakinan bahwa pada saat suami atau kerabat yang laki-laki turun ke laut istri/para perempuan dilarang untuk meninggalkan rumah. Mereka wajib berdiam di dalam rumah sambil berdo'a untuk keselamatan suaminya atau kerabatnya dan diberikan hasil tangkapan yang banyak.

Dari segi mata pencaharian hidup komunitas Lungkak mayoritas bekerja sebagai nelayan. Baik mereka sebagai punggawe, sabi(tambahkan keterangan keduanya ini apa?) atau nelayan yang bekerja sendiri dan tidak menpunyai juragan dan atau tenaga kerja/ anak buah. Sebagian yang bekerja sebagai pegawai, petani dan lain-lain. Menurut informasi tokoh masyarakat setempat bahwa sekarang ini banyak warga setempat yang tidak mau lagi bekerja sebagai sabi khususnya laki-laki karena diyakini dengan berprofesi sebagai nelayan tidak banyak mendatangkan uang. Sebagai gantinya para juragan mendatangkan sabi dari luar Dusun Lungkak. Anak-anak muda Lungkak baik laki-laki maupun perempuan lebih banyak yang menjadi Tenaga Kerja Indonesia (TKI) di luar negeri seperti Malaysia, Singapura, Korea dan Saudi Arabia karena mereka menganggap bahwa dengan menjadi TKI mereka akan mendapatkan banyak pengahasilan.

Jenis-jenis ikan yang biasa diperoleh (ditangkap) oleh para nelayan yang ada di Dusun Lungkak desa Tanjung Luar sangat beranekaragam baik jenis, ciri-ciri, rasa maupun jumlahnya. Adanya keanekaragaman ini tentunya berpengaruh terhadap tinggi rendahnya harga penjualan di pasar. Jenisjenis ikan yang dimaksud yaitu antara lain: ikan trijo, Tongkol, Cumi-cumi, Layang, Cotek, Tamban, Duluq, Asaq-asaq, Layur, Nyanggi, Biotos, Talang, Kotok, Tabbao, Oras, Ikan Joget, Ikat Bembeq, Cingor, Mereq, Koeje, Tambaq, Pantoq Empat, Merekong, Udang, Cepak, Tanggor, Pai/Pari, Buntak.
Jenis-jenis ikan tertentu harus ditangkap dengan alat tertentu. Jenis ikan yang paling banyak ditangkap adalah ikan trijo yang ditangkap dengan menggunakan jala weh. Jenis ikan ini merupakan ikan yang paling banyak populasinya, terutama di sekitar dusun Lungkak desa Tanjung Luar. Banyak sedikitnya ikan trijo yang diperoleh oleh nelayan itu juga dipengaruhi oleh musim. Musim kemarau adalah waktu munculnya banyak ikan tersebut sedangkan pada musim hujan ikan ini mulai berkurang.

Selain itu ada juga ikan yang jarang didapat oleh para nelayan yaitu ikan cotek. Ikan jenis ini ditangkap dengan jala rompoh. Ikan lain yang jarang didapat di sekitar laut di Dusun Lungkak desa Tanjung Luar yaitu ikan tongkol. Ikan ini banyak terdapat di lautan lepas yang di sekitar pulau Sumbawa, pulau Maringkik dan lain-lain. Ikan ini banyak berada di tengah-tengah laut dan biasanya ditangkap dengan menggunakan perahu besar (kapal besar) atau juga sampan besar.

Hasil tangkapan ikan biasanya dijual di pasar Tanjung Luar melalui pedagang perantara, terutama jika hasil tangkapan berlimpah. Sedangkan jika hasil tangkapan mereka sedikit, mereka menjual langsung di tepi pantai saat nelayan pulang melaut. Para pembeli (penjali) sudah menunggu kedatangan para nelayan untuk membeli ikan yang diperoleh. Pengangkutan hasil ikan ke tempat penjualan dilakukan dengan menggunakan kapal nelayan secara langsung tetapi jika dalam kondisi banjir penjualan akan mengalami kesulitan.

Para nelayan umumnya menjual hasil tangkapannya ke pasar Tanjung Luar melalui pedagang perantara. Hal ini dilakukan untuk mengantisipasi jika mengalami kekurangan keuangan. Pedagang perantara tersebut akan mencukupi kebutuhan keuangan dengan memberikan pinjaman atau hutang termasuk kepada punggawa.

Hasil penjualan ikan yang diperoleh para nelayan jumlahnya sangat bervariasi tergantung dari jumlah ikan yang didapat dan tergantung dari harga ikan di pasaran. Jika berhasil menangkap banyak ikan, nelayan bisa memperoleh uang 5 juta rupiah dalam sekali melaut, namun ada kalanya hanya 
memperoleh \pm 10.000 rupiah bahkan sama sekali tidak mendapatkan ikan. Saat ini jenis ikan yang paling mahal adalah cumi-cumi. Tingginya harga cumi-cumi disebabkan karena jenis ini banyak digemari orang dan cara penangkapannya sangat sulit. Harga cumi-cumi basah 1 ekor berkisar RP. 1000 - 3000 untuk ukuran besar, sedangkan yang kecilnya harganya berkisar Rp. 500. Harga cumi-cumi kering mencapai Rp. 40.000/kg dan yang basah sekitar Rp. 300.000/bak. berat satu bak kurang lebih $8 \mathrm{~kg}$

Selain mencari ikan, para nelayan tidak hanya menangkap ikan tetapi juga mengambil hasil laut yang lain seperti rumput laut. Terdapat beberapa jenis rumput laut yaitu rumput laut yang warnanya hijau agak putih dan merah. Rumput laut dijual ke pasar untuk menambah pendapatan di samping hasil dari menangkap ikan. Harga rumput laut akan naik saat langka diperoleh, yaitu mencapai sekitar Rp. 30.000 per bak. berat per bak kurang lebih $5 \mathrm{~kg}$ sedangkan saat berlimpah harganya jatuh mencapai Rp. 10.000$15.000 /$ bak. Hasil lain yang didapat dari laut adalah base/keke (sejenis kerang), namun itu hanya didapatkan dalam kondisi air surut. Harga base/keke adalah Rp. 20 ribu/setengah bak. Harga base/keke termasuk mahal karena sulit didapat

Para nelayan yang tinggal di dusun Lungkak desa Tanjung Luar tidak hanya melaut di sekitar wilayah mereka saja tetapi hingga ke luar wilayah perairan mereka, salah satunya keke Sumbawa, Sumba, pulau Maringkik, Tanjung Ringgit, Labu Pandan, dan lain-lain. Para nelayan yang melaut hingga ke luar wilayah harus dilengkapi surat izin penangkapan ikan (melaut) yang dibuat di kepala desa mereka. Tujuannya supaya mereka dapat menangkap ikan dengan leluasa. Apabila tidak membawa surat izin mereka akan dikeroyok oleh nelayan lain atau diharuskan membayar jika tetap ingin melaut, tapi jika tidak membayar akan disuruh pulang.

Para nelayan bebas menangkap ikan dimanapun selama masih di wilayah laut di sekitar dusun Lungkak desa Tanjung Luar. Saat melaut para nelayan tidak memiliki peraturan, siapa saja bebas untuk melaut hanya saja tidak diperkenankan menggunakan jala harimau/jala besar dan jala mini (ukurannya lebih kecil dari jala besar). Penggunaan Jala besar/jala harimau diatur melalui peraturan (awik-awik) karena jala tersebut hanya dipakai/dimiliki oleh kapal besar. Jala tersebut memiliki lubang jarring yang rapat sehingga dapat menyaring semua ikan baik yang besar maupun yang kecil sehingga sangat merugikan nelayan yang memiliki perahu kecil dan dengan jala yang sederhana.

Para nelayan memiliki pengetahuan tentang letak/lokasi rumah ikan. Menurut para nelayan, rumah ikan berada di Gaura,yaitu di sebelah timur pulau Tanjung Ringgit. Untuk mencapai tempat itu diperlukan waktu 2-3 hari pada cuaca baik. Sedangkan dalam kondisi cuaca buruk bisa mencapai 1 minggu. Jenis ikan yang paling banyak terdapat di Gaura adalah cumi-cumi, pari, ikan joget, layah, preang, tongkol, ikan bembeq, dan lain-lain. Tempat ikan yang paling banyak berada di tengah-tengah dan di pinggir lautan. Di tengah lautan banyak terdapat ikan yang agak besar sampai ikan yang paling besar sedangkan kalau yang dipinggir itu yang banyak adalah ikan teri. Aktivitas menangkap ikan di pinggir pantai disebut dengan Ngerabus. Ngerabus dilakukan apabila tidak ada ikan yang didapat di tengah laut.

Tempat banyaknya ikan (letak rumah ikan) itu tidak diberi tanda karena ikan sifatnya tidak menetap dan selalu mengikuti arus, kecuali kalau memancing, lokasi memancing diberi tanda bendera. Tujuannya agar tidak diambil alih oleh orang lain. Para nelayan mengetaui banyak sedikitnya ikan dari jala (jaring) kalau siang dan dari lampu kalau malam yaitu terutama jika akan menangkap cumi-cumi dimana cumi-cumi akan bermunculan jika melihat mampu.

Ikan memiliki pola musim artinya ia bisa bermunculan pada musim dan waktu tertentu dan dapat berkurang pada musim dan waktu tertentu pula. Menurut para nelayan pada bulan Juli sampai Desember jenis ikan yang paling banyak adalah cumi-cumi, sedangkan pada bulan Januari sampai Mei yang paling banyak adalah ikan tongkol, trijo, dan lain-lain. Adapun jenis ikan yang banyak muncul pada musim hujan adalah cu- 
mi-cumi, udang dan ketumbung. Sedangkan jenis ikan yang banyak muncul pada musim kemarau adalah ikan trijo, trilayang, nyanggi cotek, doloq dan lain-lain. Ikan yang banyak muncul pada musim hujan akan berkurang pada musim kemarau dan sebaliknya ikan yang banyak muncul pada musim kemarau akan berkurang pada musim hujan. Pada malam hari para nelayan melaut dengan menggunakan lampu namun saat menjelang fajar tidak memakai lampu. Dalam melaut mereka memiliki prinsip "ada air ada ikan".

Pada malam hari para nalayan akan menggunakan lampu agar menarik ikan-ikan dan cumi-cumi akan bermunculan di sekitar cahaya lamput. Tetapi saat bulan purnama ikan yang muncul berkurang. Hal ini karena terangnya cahaya bulan bercampur dengan cahaya dengan cahaya lampu nelayan mampu menembus sampai ke dalam laut sehingga ikan dan cumi-cumi dapat bergerak kesana kemari sehingga sulit untuk ditangkap.

Para nelayan tetap pergi melaut pada musim hujan dan musim panas (kemarau). Mereka tidak melaut hanya apabila ada halangan yang mendadak seperti sakit, cuaca yang sangat buruk, ada keluarga/tetangga yang meninggal, atau sampannya rusak. Cara penangkapan ikan pada siang hari dan malam hari berbeda. Terutama dalam hal penggunaan alat. Selain itu perbedaan cara tangkap juga ditentukan oleh jenis ikan yang akan ditangkap serta kondisi musim.

Para nelayan di dusun Lungkak desa Tanjung Luar, memiliki kemampuan dalam membaca tanda-tanda di laut maupun di angkasa untuk mengetahui kondisi/keadaan laut, sehingga dapat mengantisipasi terhadap kendala/rintangan yang mungkin terjadi. Beberapa tanda tersebut antara lain yaitu:

Tanda-tanda di laut yang dikenali seperti adanya gurita yang menyala. Bila mendapati hal itu maka para nelayan tidak boleh berbicara karena akan mengakibatkan bahaya seperti datangnya ombak yang besar. Para nelayan menyebutnya dengan istilahnya bingkai yaitu arus air laut yang memutar-mutar di bagian tengah. Kondisi arus yang demikian tentunya menjadi kendala / rintangan para nelayan di dalam melaut yaitu badai, ombak yang besar dan pasang surut air laut.
Sedangkan tanda-tanda di angkasa yaitu seperti mendung (awan hitam), halilintar (kisap), langit, dan bintang.

Bagi para nelayan, jika sudah sampai di tengah laut dan datang angin, mereka dapat mengetahui arah datangnya angin tersebut yaitu dengan cara melihat ombak. Jika angin datang, dari arah barat maka ombaknya lebih besar dan keras hingga naik 2 m sedangkan jika angin berasal dari sebelah timur ombaknya tidak terlalu besar/keras tetapi naiknya sama yaitu naik $2 \mathrm{~m}$.

Selain itu, perbedaan antara angin barat dan angin timur yaitu kalau angin barat, ketika angin datang, ombaknya juga datang dan ketika anginnya sudah tidak ada ombaknya juga akan kembali seperti semula. Sedangkan angin timur, kadang ombaknya lebih dahulu datang atau terkadang anginnya. Kondisi akan kembali normal setelah sekitar 4 jam. Angin barat dan angin timur datang tidak tentu, kadang datangnya siang dan kadang juga malam. bahkan kadang juga dating bersamaan hingga bertabrakan/ bersamaan.

Para nelayan di dalam melaut juga melihat bintang sebagai tanda-tanda di dalam melaut. Bintang yang digunakan untuk melihat kondisi laut salah satunya digunakan sebagai petunjuk arah yaitu bintang Tenggale Bentuknya seperti tenggale (alat untuk membajak sawah yang terbuat dari kayu). Bintang ini berada di sebelah timur dan biasanya muncul dari bulan Agustus-Desember. Jika bintang ini muncul maka ikan juga banyak.

Bintang Rowot Dikatakan rowot karena jumlahnya sangat banyak yaitu seperti rowot (daun asam yang masih muda). Bintang ini muncul di sebelah timur pada sekitar bulan Agustus-Desember. Jika bintang ini muncul maka ikan akan banyak naik ke permukaan.

Bintang Tegedoq Bute Bintang ini sebenarnya ada 2 yaitu bintang Tegedoq dan bintang Bute, tetepi karena keduanya selalu muncul bersamaan dan letaknya berdekatan, sehingga disebut bintang Tegedoq Bute. Bintang ini muncul di sebelah selatan pada sekitar bulan Januari-Juli, bintang ini akan hilang ningga menjelang pagi. Juka bintang ini muncul maka angin akan datang dari se- 
belah selatan. Kemunculan bintang ini menjadi tanda akan banyaknya ikan trijo.

Ketiga bintang tersebut tidak digunakan sebagai pertanda bahaya melainkan digunakan sebagai petunjuk arah termasuk juga waktu untuk melaut (baik ketika menjelang pagi maupun sore). Bintang yang digunakan untuk melihat waktu saat menjelang pagi dinamakan bintang perekmenah. Tandatanda lain dikenali dengan melihat jam dan juga tanda adalah air laut agak bercahaya (mengkilat).

Adapun yang menjadi pertanda bahaya sekaligus sebagai rintangan para nelayan dalam melaut adalah awan hitam (mendung), hujan dan kisap (halilintar). Kisap sebagai pertanda bahaya dapat dilihat/diketahui dengan cara yaitu jika kisap tersebut Nampak seperti angka satu dan berada di sebelah barat berarti pertanda bahaya, tetapi jika tidak seperti angka satu dan berada di mana-mana itu tandanya tidak berbahaya.

Masyarakat yang ada di Dusun Lungkak Desa Tanjung Luar sebagian besar bermata pencaharian sebagai nelayan atau menggantungkan hidup mereka pada laut yaitu dengan memanfaatkan kekayaan laut termasuk ikan-ikan yang ada dan yang lainnya seperti base/keke dan geranggang (rumput lau). Menurut mereka laut sangatlah penting terutama untuk mencukupi kebutuhan sehari-hari. Dalam pandangan mereka laut adalah milik semua orang sehingga siapapun boleh melaut/mencari ikan.

Para nelayan yang ada di Dusun Lungkak terdiri dari 2 golongan yaitu golongan punggawa (pemilik perahu) dan golongan sabi (pekerja/orang yang bekerja pada punggawa). Di Dusun Lungkak, sabi lebih banyak daripada punggawa. Untuk mencari sabi para punggawa merasa kesulitan karena mereka harus mencari sabi yang tekun dan tidak pindah ke punggawa lain. Kadang pencarian sabi dilakukan sampai di luar Dusun Lungkak karena para punggawa dapat memiliki sampan tiga hingga empat sampan.

Pada saat melaut, 1 sampan itu biasanya dinaiki oleh 4 atau 5 orang yang terdiri dari 1 punggawa dan 3 atau 4 sabi. Sampan yang besar itu bisa dinaiki samapi 7 orang yang terdiri dari satu punggawa dan 6 sabi.
Hasil tangkapan dibagi menjadi 10 bagian. Punggawa mendapat 2 bagian, jaring mendapat 1,5 bagian, lampu 1 bagian, sampan 1 bagian, mesin 1,5 bagian sedangkan sabi masing-masing mendapat 1 bagian. Sehingga apa bila dikalkulasi Punggawa akan mendapatkan bagian 7 bagian karena membawa alat sedangkan 3 orang sabi akan mendapatkan 3 bagian.

Hubungan antara punggawa dan sabi di dalam melaut kadang-kadang sering terjadi perselisihan. Perselisihan yang terjadi biasanya berupa adu mulut saja tidak sampai terjadi adu fisik. Perselisihan akan terjadi jika ada perbedaan pendapat antara punggawa dan sabi saat menentukan arah pencarian ikan. Misalnya sabi menginginkan ke arah barat, tetapi punggawa ingin ke timur, selain itu juga disebabkan karena sabi malas membawa barang perlengkapan melaut. Perselisihan yang terjadi biasanya cukup diatasi dengan teguran saja atau juga kadang berhenti dengan sendirinya.

Perselisihan tidak hanya terjadi antara punggawa dan sabi tapi juga antara nelayan yang satu dengan yang lain. Perselisihan yang terjadi disebabkan oleh beberapa hal yaitu "nempel" nelayan satu mendekati nelayan lain saat menangkap ikan sehingga lampu yang dibawa saling berdekatan. Perselisihan umumnya hanya berupa pertengkaran adu mulut.

Penggunaan jala harimau/seret/jala besar seringkali juga menimbulkan konflik dinatar nelayan, karena jala tersebut sangat merugikan nelayan. Jala harimau/seret/jala besar dapat menjaring habis semua ikan mulai dari yang besar sampai yang kecil. Jala harimau bisanya digunakan oleh kapal besar. Para nelayan yang menggunakan sampan kecil akan menegur nelayan yang menggunakan jala harimau, tetapi kalau tidak diikuti mereka akan menghancurkan jala harimau tersebut dan mengambil ikan-ikannya beramai-ramai. Hal seperti ini pernah terjadi pada tahun 1987-an hingga terjadi perkelahian antara para nelayan yang memiliki sampan kecil dengan nelayan yang memiliki jala harimau. Perselisihan tersebut berlangsung hingga terjadi penyerangan dengan membawa kayu, tongkat, batu dan lain-lain kepada 
nelayan pengguna jala harimau. Perselisihan akan terjadi jika kapal besar tersebut tidak mau dinasehati dan melanggar awik-awik (peraturan lokal) yang melarang penggunaan jala besar/harimau dipantai sekitar 3 mil dari pesisir pantai. Tetapi sekarang itu sudah tidak terjadi lagi, kalaupun ada jala harimau yang beroperasi kurang dari 3 mil atau melanggar awik-awik akan ditegur atau dirusak alat-alatnya dan mengambil hasil tangkapannya.

Hubungan kerja sama dan tolong menolong pada masyarakat nelayan yang ada di dusun Lungkak itu tidak hanya dilakukan dengan sesama nelayan yang berasal dari dusun Lungkak saja tetapi dengan semua nelayan yang berasal dari tempat atau daerah yang berbeda.

Para nelayan yang ada di dusun Lungkak jarang melakukan musyawarah karena adanya keterbatasan waktu artinya mereka jarang dapat kumpul disebabkan oleh aktivitas mereka yang selalu melaut. Kegiatan seperti bakti sosial, siskamling sering dilakukan oleh pemuda. Sehingga golongan muda lebih aktif dalam berpartisipasi dalam berbagai kegiatan sosial.

Pada masyarakat nelayan yang ada di dusun Lungkak desa Tanjung Luar sering melakukan kegiatan upacara/ritual diantaranya adalah upacara selamatan sampan baru dan selamatan laut.

Upacara selamatan sampan baru dilakukan dengan membaca dzikir bersama para nelayan yang lain. Zikiran tersebut dipimpin oleh seorang kyai (ustadz). Dalam upacara tersebut disediakan sesaji yang terdiri dari kemenyan, beras tumbuk yang dicampur dengan Kunyit dan daun Parempes. Tujuan upacara ini adalah supaya sampan dan pemiliknya termasuk para sabi akan selalu selamat saat melaut dan mendapat rezeki yang banyak.

Pelaksanaannya dzikiran dilakukan di atas sampan yang masih berada di darat. Pada waktu dzikiran dkyai membakar kemenyan sambil berdzikir diikuti oleh orangorang yang hadir. Setelah itu lalu berdoa. Selesai berdoa beras tumbuk yang telah di campur dengan kunyit dan daun perampes diambil dan dioles-oleskan ke seluruh ba- gian sampan. Setelah itu orang yang ikut dalam dzikiran tersebut diberi makanan. Janis makanan yang tidak boleh terlupakan adalah bubur atau rekambang, dalam bahasa bajonya disebut lungkak. Pelopo atau orang yang bertugas membawa sesajian adalah perempuan. Tidak ada ketentuan apapun bagi perempuan yang membawanya, siapa saja boleh membawa sesajen itu asalkan ia perempuan. Upacara ini bisanya disebut dengan istilah Tampoh Tawar Sampan artinya selamatan sampan dan pemilikannya.

Selain upacara selamatan sampan para masyarakat nelayan di dusun lungkak desa Tanjung Luar juga melakukan suatu upacara secara besar yaitu upacara selamatan laut. Upacara ini tidak pernah ditinggalkan dan bahkan merupakan suatu kegiatan yang diharuskan/diwajibkan karena sudah menjadi tradisi tahunan yang diselenggarakan oleh masyarakat Tanjung Luar. Upacara ini dilakukan karena para nelayan yakin bahwa laut terdapat penghuni yang tidak bisa dilihat dan berbentuk jin. Tujuan dilakukan upacara tersebut supaya ikan banyak yang muncul dan para nelayan juga selamat ketika melaut dan mendapat ikan yang banyak. Upacara ini bisanya dilakukan 1 kali dalam 5 tahun. Jika upacara ini tidak dilakukan maka akan terjadi suatu musibah seperti banyak yang kerasukan setan, ikan tidak ada pendapatan nelayan tidak sedikit dan akan terjadi sesuatu hal yang tidak diinginkan ketika melaut.

Adapun yang dibutuhkan di dalam upacara tersebut adalah kepala kerbau, kemenyan, emas (seperti anting, cincin), ayam, beras hitam (beras yang digoreng sampai gosong tapi tanpa minyak), beras putih, beras kuning, (beras yang dicampur dengan kunyit) empok-empok (beras yang digoreng tanpa minyak). Tebu yang dipotong kecilkecil, makanan seperti ketupat, tikel, dan semua jenis makanan tradisional. Selain itu juga memerlukan kain putih dan alat pengiring yaitu gendang seruni. Upacara tersebut menggunakan kerbau karena marupakan upacara besar-besar tetapi kalau upacara kecil-kecilan menggunakan kambing. Upacara tersebut menggunakan emas karena sebagai bukti terima kasih kepada penghuni laut atau sebagai penghargaan dimana semua itu dibe- 
li dari hasil melaut. Ayam digunakan untuk sebagai sesaji untuk mangku. Upacara tersebut dipimpin oleh mangku/sandro. Untuk dapat menjadi mangku/sandro harus dari keturunan asli bajo yang memiliki ilmu tertentu yaitu mampu berbicara dengan makhluk halus jin/penghuni laut tersebut.

Adapun prosesi upacara tersebut adalah sebagai berikut a). Tujuh hari sebelum upacara dimulai kerbau itu diajak jalan-jalan di tepi pantai dengan diiringi oleh gedang seruni dan diikuti oleh para penari keturunan Bajo asli. Penari itu terdiri dari laki-laki dan perempuan baik tua maupun muda. Selain itu yang juga diikuti mangku/sandro dan masyarakat lainnya. Ascara itu biasanya dilakukan saat sore setelah sholat asar sampai saat magrib. Semua pengiring menggunakan pakaian hitam dengan ikat kepala yang berlainan. Sedangkan sandro itu menggunakan pakaian dan ikat kepala serba hitam. b). musik gendang seruni dibunyikan setiap malam sampai tiba pelaksanaan upacara tersebut. $\mathrm{Mu}-$ sik tersebut juga diikuti oleh tarian adat yang mana para penari tersebut menari di panggung dekat rumah sandro yaitu di kampung Tengaq (Desa Tanjung Luar) penari menggunakan pakaian adat Bajo (pakaiannya seragam) tapi ikat kepalanya berlainan. Penari wanita ikat kepalanya merah sedangkan kalau laki-laki warnanya hitam, c). setelah tiba hari ke-7 atau waktu upacara dimulai mang$\mathrm{ku} /$ sandro memasang cincin/anting emas seberat 2-3 gram pada tanduk kerbau. Setelah itu kerbau dipotong oleh seorang kyai atau orang yang dipercayakan dapat memotong atau menyemblih kerbau. Setelah kerbau tersebut dipotong, kepalanya diambil diambil karena menurut kepercayaan mereka yang diinginkan oleh penghuni laut adalah kepala kerbau. Sedangkan bagian lainnya dibagikan kepada masyarakat secara merata. Pemotongan kerbau tersebut dilakukan pada malam hari, kepala kerbau yang sudah terpotong itu kemudian oleh mangku/sandro diletakkan di atas kain putih kemudian dimasukkan ke dalam rakit dari bambuyang disertai dengan sesaji. Setelah itu rakit tersebut dibawa ke rumah penggung milik mangku/sandro. Sampai di rumah mangku/sandro rakit tersebut ditaruh di ditempat khusus. Mangku/sandro membacakan mantra disertai dengan membakar kemenyan. Keesokan harinnya. yaitu ketika upacara akan dimulai, rakit dibawa ke pantai oleh mangku/sandro dengan berjalan kaki diiringi oleh orang-orang asli Bajo yang berasal dari setiap dusun yang ada di desa Tanjung Luar. Pengiring tersebut berpakian serba hitam dengan ikat kepala yang berbeda sambil membawa tombak pusaka. Selain itu, juga diiringi oleh gedung seruni dan para penari dan juga semua masyarakat mulai dari yang kecil sampai yang tua. Pada saat berlangsungnya upacara para pengiring dan penari memakai ikat kepala yang berbeda karena menurut mereka hal itu menunjukkan bahwa penghuni laut itu bermacam-macam rupa dan bentuknya termasuk ada yang baik dan ada juga yang jahat.

Setelah sampai di pinggir pantai, sandro dan pengiringnya beserta rakit berisi kepala kerbau naik ke sampan yang paling besar. Orang yang membawa alat musik gendang seruni beserta penari naik di sampan yang lain. Masyarakat ikut mengiringi dengan menaiki sampan yang lain. Ada juga masyarakat hanya menunggu dipinggir pantai. Setelah semuanya siap sampan tersebut melaju ke tengah laut untuk mencari batu daenq bangkiq yang letaknya di depan desa Tanjung Luar. Batu tersebut kadang-kadang kelihatan dan kadang tidak. Batu tersebut akan kelihatan saat sesji berupa kepala kerbau tersebut akan dibuang.

Setelah sampai di tengah laut, sampan berisi kepala kerbau berada di barisan posisi paling depan. Sesampainya di sekitar tempat batu batu daeng bangkiq berada sampan itu akan mengitarinya sebanyak 3 kali. Sampan lain tidak ikut memutar dan hanya menunggu saja, di dekat sampan sandro. Setelah batu yang dicari tampak, semua orang yang berada di tempat itu tidak diperbolehkan berbicara. Apa bila larangan itu dilanggar, akan mengakibatkan adanya musibah seperti kedongkoan atau kesurupan. Akibat lainnya ikan tidak ada yang naik ke permukaan Satu-satunya orang yang boleh berbicara hanyalah sandro yang membaca mantra sambil membakar kemenyan. Setelah itu batu daeng bangkiq akan membelah lalu sandro/ mangku menusuk kepala kerbau yang ada di 
dalam rakit dengan menggunakan tombak pusaka, dan melemparkan kepala kerbau itu ke celah batu yang membelah. Tombak kemudian ditarik hingga terlepas dari kepala kerbau. Kalau kepala kerbau itu muncul lagi sandro akan kembali menusuknya dengan tombak dan melemparnya kembali ke celah batu. Tindakan itu hanya dapat diulang sebanyak 3 kali saja tidak boleh lebih. Setelah kepala kerbau dilemparkan maka air laut di sekitarnya akan memutar dan akhirnya menghilang. Saat kepala kerbau menghilang berarti acara selesai dan orang-orang boleh berbicara. Orang-orang akan bersorak sorai, saling melempar makanan yang dibawa, saling menyiram air. Sandro akan diceburkan ke laut diikuti oleh yang lainnya. Hal itu dilakukan sebagai ekspresi rasa senang

Jika kepala kerbau tetap muncul setelah dilemparkan hingga 3 kali, maka hal itu menjadi pertanda bahwa penghuni laut tersebut tidak menerima sesajian itu. penyebabnya karena adanya suatu kesalahan pada pelaksanan upacara tersebut sehingga perlu mengulang upacara Tetapi jika kepala kerbau itu tidak muncul menandakan penghuni laut menerimanya. Tanda ini dapat diketahui setelah hari ke 4 setelah acara dilaksanakan.

Prosesi itu selesai ketika menjelang malam, kemudian dilakukan pesta selama 3 malam. Pesta ini berupa pesta kecil-kecilan dengan mengadakan pertunjukan dan perlombaan permainan tradisional kuntauq atau joget silat. Setelah upacara tersebut dilakukan, para nelayan tidak boleh pergi melaut hingga 1 minggu. Setelah tiba saatnya melaut maka ikan akan lebih banyak didapat daripada sebelumnya.

Selama berlangsungnya upacara tersebut semua masyarakat ikut berpartisipasi dan ikut terlibat dengan masing-masing keluarga mengeluarkan uang untuk membeli segala yang dibutuhkan seperti kerbau, emas dan lain-lain. Hal ini juga dapat dilihat dari antusiasme para nelayan dalam membuat hiasan pada sampan. Semua sampan itu dihias sesuai dengan keinginan dan kemampuan masing-masing nelayan.

Adapun pantangan-pantangan bagi para nelayan di dalam melaut baik bagi nelayan itu sendiri maupun bagi keluarga yang ditinggalkan di rumah yaitu tidak boleh menggosok panci dan tidak boleh bersisir ketika akan melaut karena kalu itu dilakukan maka ikan yang didapat sedikit dan akan terjadi sesuatu yang tidak diinginkan.

\section{SIMPULAN}

Pembahasan di atas menunjukkan bahwa komunitas nelayan Lungkak mempunyai sistem budaya kenelayanan berupa sistem pengetahuan tentang kenelayanan yang sampai sekarang masih melekat erat dalam kehidupannya. Sistem pengetahuan ini merupakan hasil berpikir dan menyesuaikan kondisi lingkungannya di mana mereka berada. Pengetahuan ini berupa pengetahuan tentang biota laut bernilai ekonomi, pengetahuan tentang tempat penangkapan dan posisi rumah ikan, pengetahuan tentang musim (pola musim dan waktu-waktu munculnya ikan), pengetahuan tanda-tanda di laut dan di angkasa serta sistem keyakinan/kepercayaan (upacara/ritual dan pantangan-pantangan).

Kemudian komunitas Lungkak bersama komunitas nelayan lainnya yang berada di dalam tiga kawasan yang ada di Lombok Timur membuat kesepakatan untuk menciptakan awig-awig yaitu suatu aturan tentang pengelolaan dan pemanfaatan sumber daya kelautan demi terciptanya sumber daya alam yang lestari atau berkelanjutan. Walaupun aturan-aturan ini dibuat dengan menyesuaikan dengan kondisi lingkungan serta kondisi sosial budaya komunitas yang ada di dalam tiga kawasan tersebut. Ini terlihat adanya perbedaan dalam pemanfaatan dan pengelolaan sumber daya kelautan di mana pada komunitas nelayan Lungkak yang bertipe nelayan pemburu ikan sangat melarang penangkapan ikan dengan menggunakan teknologi bagang ataupun teknologi budidaya keramba. Kenyataan ini menunjukkan bahwa walaupun aturan-aturan pemanfaatan sumberdaya kelautan dibuat bersama namun tetap harus disesuaikan dengan kondisi lingkungan dan sosial budaya masing-masing komunitas.

Sistem budaya yang dimiliki dan dipraktekkan oleh nelayan Lungkak ini merupakan pegangan atau pedoman dalam rangka hidup dan penghidupannya sebagai nelayan. 
Pedoman inilah yang akan dipegang dalam proses kenelayanan dan diharapkan dengan mempedomani sistem budaya mereka bisa meminimalisir kemungkinan-kemungkinan yang akan terjadi selama proses penangkapan ikan yang mana laut sebagai lahan pencaharian hidup nelayan dikenal sebagai lahan yang tidak menentu.

Dari hasil penelitian di atas dan pengamatan peneliti selama beberapa bulan mengadakan penelitian di komunitas nelayan Lungkak maka ada beberapa rekomendasi saran kepada pamerintah sebagai penentu kebijakan dalam pembangunan supaya lebih banyak memperhatikan masyarakat nelayan di manapun mereka berada. Kenyataan yang ada bahwa komunitas nelayan mayoritas masih hidup miskin khususnya nelayan kecil baik itu yang mengoperasikan sendiri perahunya ataupun ikut menjadi anak buah atau tenaga kerja pada seorang juragan. Para nelayan kecil seakan terjebak di dalam sebuah pola hubungan kerja nelayan yang merugikan mereka tanpa bisa berbuat banyak apalagi berubah menjadi nelayan mandiri yang bisa mengangkat derajat sosial ekonominya.

Pemerintah bisa menciptakan program-program yang menguntungkan bagi nelayan kecil tidak hanya keuntungan jangka pendek tapi juga jangka panjang, sehingga para nelayan kecil bisa mandiri dalam menjalankan usahanya dan keluar dari pola-pola hubungan kerja nelayan yang hanya memihak pada juragan-juragan.

\section{DAFTAR PUSTAKA}

Acheson, James, M. 1981. Anthropology of Fishing.
Annual Review of Anthropology. Vol. 10: 275-316.

Badan Pusat Statistik. 2010. Perkembangan Beberapa Indikator Utama Sosial-Ekonomi Indonesia. Badan Pusat Statistik: Jakarta

Durrenberger, E. Paul and Gisli Palsson. 1986. Finding Fish: The Tactics of 1celandic Skippers. American Ethnologist 13(2):213-29.

Folke, C. 2004. Traditional knowledge in social-ecological systems. Ecology and Society 9(3): 7

Geertz, C. 1984. Culture and Social Change: The Indonesian Case. Man (N.S) 9: 511-532.

Kalman, Judy dan María de los Ángeles Liceaga Correa. 2009. The coexistence of local knowledge and GPS technology: Looking for Things in the Water. MAST 8(2): 9-34

Lampe, M. 2003. Budaya Bahari dalam Konteks Global dan Modern (Kasus komuniti-komuniti Nelayan di Indonesia). Makalah dalam Kongres Kebudayaan V di Bukit Tinggi Sumatra Barat Tanggal 20-23 Oktober 2003.

McCay, BJ. 1980. A Fishernlen's Cooperative, Limited: Indigenous Resource Management in a Complex Society. Anthropological Quarterly 53(1):29-38

Naping, H. 2003. Teknologi dan Pemanfaatan Lingkungan Laut bagi Nelayan Bagang Rambo di Sulawesi Selatan. Makalah dalam Kongres Kebudayaan V di Bukit Tinggi Sumatra Barat Tanggal 20-23 Oktober 2003.

Palsson, Gisli. 1988. Models for Fishing and Model of Success. MAST 1(1):15-28

Palmer, Craig T. 1989. The Ritual Taboos of Fishermen: An Alternative Explanation. MAST 2(1):59-68

Poggie, J.J. Jr. 1980. Ritual Adaptation Risk and Technological Development Ocean Fisheries: Exploitation from New England. Anthropological Quarterly 53(1):122-129

Poggie, J.J. Jr., R. Pollnac dan C. Gersuny. 1976. Risk as a Basis for Taboos among Fishermen in Southern New England. Journal for the Scientific Study of Religion 15(3):257-62

Smith, E. Estelle. 1988. Fisheries Risk in Modern Context. MAST 1(1): 29-48

Spradley, James., 1997 Metode Etnografi (terjemahan). Yogyakarta, PT. Tiara Wacana. 